\title{
Multiple-locus heterozygosity, physiology and growth at two different stages in the life cycle of the Chilean oyster Ostrea chilensis
}

\author{
Jorge E. Toro ${ }^{1, *}$, Ana M. Vergara ${ }^{1}$, Ricardo Gallegillos ${ }^{2}$ \\ ${ }^{1}$ Instituto de Biología Marina, Universidad Austral de Chile, Casilla 567, Valdivia, Chile \\ ${ }^{2}$ Universidad Católica de la SSma. Concepción, Casilla 297, Concepción, Chile
}

\begin{abstract}
A random sample of 150 individuals of a laboratory-produced cohort of Ostrea chilensis Philippi, 1845 was taken at 10 and 36 mo of age to estimate physiological variables and individual heterozygosity usıng 4 loci $\{L a p, P g i, P g m$ and Ca\}. Juveniles of 10 mo of age showed a mean D value of $0.134(\mathrm{p}>0.05)$ and a positive correlation between oyster size and multiple-locus heterozygosity (MLH) $(p<0.05)$. Also, there was a positive correlation $(p<0.05)$ between ingestion rate, absorption rate and MLH. A negative correlation between excretion rate $(p>0.05)$, oxygen consumption rate $(p<0.05)$ and MLH was found. The $K_{2}$ value (standardized net growth efficiency) was positively correlated $(p<0.05$ ) with MLH. At 36 mo a heterozygote deficiency was present with a mean value $D=-0.431(\mathrm{p}<0.05)$. No relationship between standard dry weight and MLH and also a negative correlation between the scope for growth and MLH were found. The oxygen consumption and excretion rates also showed an increase in large size individuals. The slopes for flltration and excretion rates against MLH were negative and not statistically significant. However, ingestion and absorption rates showed significant $(p<0.05)$ decrease with an increase in heterozygosity. The results seem to indicate that within sexually immature individuals of $O$. chilensis, a positive correlation between growth rate and MLH can be found, while in adults the higher energy allocation for reproduction precludes the detection of this relationship.
\end{abstract}

KEY WORDS: Growth Heterozygosity - Ostrea chilensis Oyster Physiology

\section{INTRODUCTION}

The observation that multiple-locus allozyme heterozygosity (MLH) correlates positively and significantly with growth rate and metabolic efficiency has been made for many organisms (Mitton \& Grant 1984). Among the marine invertebrates, higher age-specific growth rate has been demonstrated with increasing mean heterozygosity at electrophoretically detectable loci in natural populations of oysters (Singh \& Zouros 1978, Zouros et al. 1980, Fujio 1982, Koehn \& Shumway 1982), mussels (Koehn \& Gaffney 1984, Diehl et al. 1986, Rodhouse et al. 1986, Gentili \& Beaumont 1988),

\footnotetext{
- Present address: Ocean Sciences Centre, Memorial University of Newfoundland, St. John's, Newfoundland, Canada A1C 5S7.E-mail: jtoro@kean.ucs.mun.ca
}

clams (Garton et al. 1984, Koehn et al. 1988) and snails (Garton 1984). Demonstration of a correlation between heterozygosity and growth rate depends on genetic structure of the population (Gaffney \& Scott 1984), accuracy of age determination, and life stage sampled. When the energy is allocated largely to somatic growth rather than to reproduction, the correlation can disappear (Rodhouse et al. 1986).

Within the context of a balanced energy budget (Thompson \& Bayne 1974), scope for growth represents the energy available for growth and reproduction, expressed as the difference between absorbed energy and energy lost through metabolic processes. According to this, the physiological basis by which more heterozygous individuals achieve higher average growth rates may include increasing metabolic efficiency (i.e. reduction of metabolic costs per unit 
weight) and/or increasing energy absorption (i.e. increased feeding rate or absorption efficiency or both). Several studies relate heterozygosity to metabolic parameters. They include standardized oxygen uptake during starvation in Crassostrea virginica (Koehn \& Shumway 1982) and Mytilus edulis (Diehl et al. 1986), weight loss during starvation in C. virginica (Rodhouse \& Gaffney 1984), protein turnover in $M$. edulis (Hawkins et al. 1986) and density-related stress in $M$. edulis (Gentili \& Beaumont 1988). A more complete study carried out in Mulinia lateralis included the measurement of several metabolic parameters and showed that 'scope for activity' was positively correlated to heterozygosity (Garton et al. 1984). We describe here an experiment in which size, physiological variables (energy budget) and MLH were measured for individual Ostrea chilensis Philippi, 1845 from a cohort produced in the laboratory and grown in the field under uniform low-density conditions until 10 and 36 mo of age.

\section{MATERIALS AND METHODS}

Oysters. A cohort of Ostrea chilensis, collected during December 1987 from a natural spatfall from the wild population of $O$. chilensis at Quempillén River Estuary in Chile $\left(45^{\circ} 52^{\prime} \mathrm{S}, 73^{\circ} 46^{\prime} \mathrm{W}\right)$, was used as parental stock. In September 1990, after 3 yr of growth under uniform conditions at Hueihue location (Chile) $\left(41^{\circ} 58^{\prime} \mathrm{S}, 73^{\circ} 30^{\prime} \mathrm{W}\right), 800$ randomly chosen oysters were taken as brood stock to produce a cohort in the laboratory. By using mass spawning it is not possible to determine how many individuals contribute genes to the offspring obtained; however, some estimation of the female contribution was made by the number in each brood of eyed larvae. The brooding oyster $O$. chilensis presents an average fecundity of 60000 larvae per season (Toro \& Chaparro 1990). Thus, from the amount of larvae released, more than $8.2 \times 10^{6}$, we assumed that at least 130 female had contributed larvae. This estimation of the female contribution may be an underestimation because in this species some of the eyed larvae released will set in as few as 5 min (DiSalvo et al. 1983). The male contribution in this experiment can be assumed (about 300 to 400 males) by the percentage of males found in the field site during the spawning season that fluctuates between 45 and $60 \%$ of the population. The brood oysters were placed in a fiberglass tank and warmed from an ambient water temperature (around $12^{\circ} \mathrm{C}$ ) to $18^{\circ} \mathrm{C}$ over a 4 wk period. Salinity during conditioning was 27 to $28 \mathrm{ppt}$, corresponding to the average salinity for the months of September to November in the estuary. The salinity variation in the Quempillen Estuary throughout the year ranges between 14 and $32 \mathrm{ppt}$ with an annual average of $26 \mathrm{ppt}$, while the temperature fluctuates between 9 and $22^{\circ} \mathrm{C}$ with an annual average of $13^{\circ} \mathrm{C}$. The water was filtered through a $5 \mu \mathrm{m}$ filter and before heating. passed through an ultraviolet (UV) sterilizing unit. The water was changed daily and a mixture of Isochrysis galbana, Clone T-iso, and Chaetoceros gracilis Schutt was added continuously to a final concentration of 50 cell $\mu^{-1}$ After $5 \mathrm{wk}$ of conditioning, clean plastic plates $(15 \times 15 \mathrm{~cm})$ were placed in the tank. The larval release and settlement occurred within $24 \mathrm{~h}$. Each collector was labeled and transferred to a common rearing tank for $5 \mathrm{wk}$. Individually tagged juveniles were grown in the field under uniform low-density conditions ( 150 oysters $\mathrm{m}^{-2}$ ) following the procedures of Toro \& Varela (1988). Samples of 150 randomly chosen oysters were collected at 10 mo of age (live weight: 0.104 to $1.570 \mathrm{~g}$; shell height: 8 to $23.8 \mathrm{~mm}$ ) and at $36 \mathrm{mo}$ of age (just after the spawning season; live weight: 8.65 to $47.2 \mathrm{~g}$; shell height: 34.6 to $66.9 \mathrm{~mm}$ ) in order to make direct, individual measurements of growth, energy budget and MLH.

Energy budget. For each individual oyster, after a period of $3 \mathrm{~d}$ of acclimatation in the laboratory, the following physiological variables were estimated or calculated, with 3 replicates each, in order to describe the energy budget at $13^{\circ} \mathrm{C}$ and 28 ppt salinity.

Filtration rate: This rate was determined indirectly by quantifying the rate of decrease in algal cell density in the experimental medium maintained in darkness (10 and $2 \mathrm{l}$ for each oyster of 36 and $10 \mathrm{mo}$ of age respectively). Initial algal concentration was $15 \times 10^{6}$ cells of Isochrysis galbana per liter (Navarro \& Winter 1982; Vergara et al. 1992). Every 2 h, algal concentration was measured by Coulter counter (ELZONE $180 \mathrm{XY}$ ) and the initial concentration restored.

Organic ingestion rate: The amount of organic food ingested per unit time (mg organic matter $\mathrm{d}^{-1}$ ) was calculated as the product of filtration rate (no pseudofaeces were observed) and organic dry weight of Isochrysis galbana (Winter et al. 1984).

Assimilation efficiency (\%): This was determined according to Conover (1966). Faeces were collected washed and dried immediately at the end of each filtration rate experiment in order to avoid decomposition.

Absorption rate: The product of ingestion rate and assimilation efficiency was expressed in joules per day $\left(\mathrm{J} \mathrm{d}^{-1}\right)$ (1 $\mathrm{mg}$ of organic material of Isochrysis galbana $=$ $18.75 \mathrm{~J}$; Whyte 1987 ).

Excretion rate: This was determined by measuring g ammonia nitrogen produced per oyster per hour (Solórzano 1969). Juvenile oysters were incubated in $100 \mathrm{ml}$ and adult oysters in $300 \mathrm{ml}$ of $0.45 \mu \mathrm{m}$ filtered seawater for $5 \mathrm{~h}$. Controls were filtered seawater from 
the same batch, without oysters, incubated at the same time. Amount of ammonia nitrogen was transformed to energy (1 $\mathrm{mg} \mathrm{NH}_{4}-\mathrm{N}=24.8 \mathrm{~J}$ ) using the coefficient of Elliot \& Davison (1975).

Respiration rate: This was measured in the apparatus described by Rios (1979). The oysters were starved for $3 \mathrm{~d}$ in filtered seawater before the experiment (standard or basal metabolism). Values for oxygen consumption were expressed in $\mathrm{ml} \mathrm{O}_{2} \mathrm{~h}^{-1}$ and transformed to energy using the coefficient of Thompson \& Bayne (1974) $(1 \mathrm{ml} \mathrm{O}=19.9 \mathrm{~J})$.

Scope for growth: This was calculated as the difference between absorbed energy and energy loss to excretion and respiration, expressed in $\mathrm{J} \mathrm{d}^{-1}$ (Warren \& Davis 1967).

Net growth efficiency $\left(\boldsymbol{K}_{2}\right)$ : The efficiency with which organic material is transformed into body tissue was the dividend of scope for growth divided by absorbed energy (Winter et al. 1984).

Electrophoresis. After physiological evaluation, oysters were placed in liquid nitrogen until electrophoresis. Starch gel electrophoresis was used to score loci for leucine aminopeptidase (Lap, EC 3.4.1.1), glucose phosphate isomerase (Gpi, EC 5.3.1.9.), carbonic anhydrase (Ca, EC 4.2.1.1) and phosphoglucomutase (Pgm, EC 2.5.7.1.) following Shaw \& Prasad (1970), Selander et al. (1971) and Ahmad et al. (1977) These 4 polymorphic loci were chosen because they have been already used in earlier studies on Ostrea chilensis (Toro \& Aguila 1995).

For each locus, observed genotypic distributions were compared with Hardy-Weinberg expectations

Table 1. Ostrea chilensis. Observed number of genotypes (Lap, Pgi, Pgm, Ca) in the cohort at 10 mo. Expected number for Hardy-Weinberg and $\chi^{2}$ is also shown. Numbers in parentheses correspond to observed and expected genotypes. ns: not significant; $N=110$

\begin{tabular}{|cllrlr|}
\hline \multicolumn{2}{l}{ Genotype } & Observed & Expected & $\chi^{2}$ & $\mathrm{p}$ \\
\hline Lap & $100 / 100$ & $0.516(56)$ & $(56.7)$ & & \\
& $100 / 90$ & $0.405(46)$ & $(44.5)$ & 0.12 & $\mathrm{~ns}$ \\
& $90 / 90$ & $0.079(8)$ & $(8.7)$ & & \\
Pgi & $100 / 100$ & $0.478(50)$ & $(52.5)$ & & \\
& $100 / 90$ & $0.426(52)$ & $(47.0)$ & 1.255 & $\mathrm{~ns}$ \\
& $90 / 90$ & $0.096(8)$ & $(10.5)$ & & \\
$\operatorname{Pgm}$ & $100 / 100$ & $0.515(60)$ & $(56.7)$ & & \\
& $100 / 95$ & $0.405(38)$ & $(44.5)$ & 2.364 & $\mathrm{~ns}$ \\
& $95 / 95$ & $0.080(12)$ & $(8.7)$ & & \\
Ca & $100 / 100$ & $0.226(22)$ & $(26.5)$ & & \\
& $200 / 100$ & $0.290(32)$ & $(27.5)$ & & \\
& $150 / 100$ & $0.290(32)$ & $(27.5)$ & 5.204 & $\mathrm{~ns}$ \\
& $200 / 200$ & $0.065(8)$ & $(7.1)$ & & \\
& $200 / 150$ & $0.065(8)$ & $(14.3)$ & & \\
& $150 / 150$ & $0.065(8)$ & $(7.1)$ & & \\
& & & & & \\
\hline
\end{tabular}

(G-test for goodness of fit) (Sokal \& Rohlf 1981). Heterozygote deficiencies were expressed as $D=\left(H_{0}-H_{e}\right) /$ $H_{0}$, where $H_{0}$ is the observed frequency of heterozygotes and $H_{\mathrm{e}}$ the expected frequency.

Observed MLH distributions were determined by counting the number of individuals heterozygous for 0 , $1, \ldots, k$ loci. Because sample sizes varied among MLH distributions, weighted least squares regressions were employed for physiological variables on MLH.

Statistics and weight standardization. Weightspecific rate functions were calculated in order to eliminate the differential weight of oysters on each physiological rate and quantify only the genetic effect (Packard \& Boardman 1988). The weight standardization was carried out using analysis of covariance (ANCOVAR) with dry tissue weight as the covariate, physiological rate as the dependent variable and the heterozygosity classes as the treatments. The appropriate regression coefficients were then used to adjust individual physiological rates.

\section{RESULTS}

The percentage mortality of experimental oysters, between settlement and 10 mo of age was $6 \%$ and between the ages of 10 and 36 mo it was $27 \%$. The 4 enzyme loci studied were in Hardy-Weinberg equilibrium in the 10 mo old juveniles (Table 1). However, in the 36 mo old oysters of the same cohort Lap, Pgm and Ca differed significantly from Hardy-Weinberg expectations with a deficiency of heterozygotes (Table 2).

Table 2. Ostrea chilensis. Observed number of genotypes (Lap, Pgl, Pgm, Ca) in the cohort at 36 mo. Expected number for Hardy-Weinberg and $\chi^{2}$ is also shown. Numbers in parentheses correspond to observed and expected genotypes. ns: not significant; $N=142 ; " \mathrm{p}<0.05$

\begin{tabular}{|c|c|c|c|c|c|}
\hline \multicolumn{2}{|c|}{ Genotype } & \multirow{2}{*}{$\begin{array}{l}\text { Observed } \\
0.438(70)\end{array}$} & \multirow{2}{*}{$\begin{array}{c}\text { Expected } \\
(62)\end{array}$} & \multirow[t]{2}{*}{$x^{2}$} & \multirow[t]{2}{*}{$\mathrm{p}$} \\
\hline Lap & $100 / 100$ & & & & \\
\hline & $100 / 90$ & $0.448(48)$ & (64) & & \\
\hline & $90 / 90$ & $0.114(24)$ & $(16)$ & 8.50 & $\cdot$ \\
\hline \multirow[t]{3}{*}{$P g i$} & $100 / 100$ & $0.690(100)$ & $(98)$ & & \\
\hline & $100 / 90$ & $0.281(36)$ & $(40)$ & 1.35 & ns \\
\hline & $90 / 90$ & $0.029(6)$ & (4) & & \\
\hline \multirow[t]{3}{*}{ Pgm } & $100 / 100$ & $0.702(108)$ & $(100)$ & & \\
\hline & $100 / 95$ & $0.272(22)$ & (38) & 26.171 & $\cdot$ \\
\hline & $95 / 95$ & $0.026(12)$ & (4) & & \\
\hline \multirow[t]{6}{*}{$\mathrm{Ca}$} & $100 / 100$ & $0.338(48)$ & (33) & & \\
\hline & $200 / 100$ & $0.099(14)$ & (38) & & \\
\hline & $150 / 100$ & $0.197(28)$ & (33) & 40.788 & • \\
\hline & $200 / 200$ & $0.169(24)$ & (11) & & \\
\hline & $200 / 150$ & $0.113(16)$ & (19) & & \\
\hline & $150 / 150$ & $0.084(12)$ & (8) & & \\
\hline
\end{tabular}


Table 3. Ostrea chilensis. Average values for $D$ in each locus (Lap, Pgi, Pgm, Ca) and weight class category and their correlations ( $r$ ) with the oyster $\log$ dry weight. $" p<0.05 ;{ }^{*} p<0.01$

\begin{tabular}{|c|c|c|c|c|c|}
\hline \multirow[t]{2}{*}{ Locus } & \multicolumn{5}{|c|}{10 months } \\
\hline & $\begin{array}{c}0- \\
0.013\end{array}$ & $\begin{array}{c}0.014- \\
0.026\end{array}$ & $\begin{array}{c}0.027- \\
0.039\end{array}$ & $>0.040$ & r \\
\hline Lap & -0.659 & 0.181 & 0.310 & 0.384 & $0.837^{\circ}$ \\
\hline Pgi & -0.206 & 0.005 & 0.390 & 0.396 & $0.613 \cdots$ \\
\hline Pgm & -0.321 & 0.211 & 0.198 & 0.486 & $0.784 \cdots$ \\
\hline $\mathrm{Ca}$ & -0.127 & 0.264 & 0.231 & 0.415 & $0.921 \cdots$ \\
\hline Mean $D$ & -0.328 & 0.165 & 0.282 & 0.420 & \\
\hline \multicolumn{6}{|c|}{36 months } \\
\hline \multirow{2}{*}{ Locus } & \multicolumn{4}{|c|}{ Oyster dry weight class (g) } & $\mathrm{r}$ \\
\hline & $\begin{array}{c}0- \\
0.360\end{array}$ & $\begin{array}{c}0.361- \\
0.720\end{array}$ & $\begin{array}{c}0.721- \\
1.080\end{array}$ & $>1.081$ & \\
\hline Lap & 0.200 & 0.150 & 0.074 & 0.060 & $-0.940^{\circ}$ \\
\hline$P g i$ & 0.124 & 0.119 & 0.217 & -0.213 & $-0.579^{\circ}$ \\
\hline$P g m$ & 0.054 & 0.096 & 0.099 & 0.083 & $0.358^{\circ}$ \\
\hline $\mathrm{Ca}$ & 0.353 & -0.430 & -0.645 & -0.357 & -0.292 \\
\hline Mean $D$ & 0.182 & -0.016 & -0.063 & -0.106 & \\
\hline
\end{tabular}

The relative viabilities (Alvarez et al. 1989) between 10 and $36 \mathrm{mo}$ for heterozygotes were 0.347 (Pgm), 0.364 $(C a), 0.710(\operatorname{Lap})$ and $0.379(P g I)$.

The 2 age classes were divided into 4 subgroups each, based on individual dry weight. Table 3 shows the distributions of $D$ for each locus and averages over loci in 4 weight groups. From the data it can be seen that the deficiency of heterozygotes is not equally distributed over weight and age classes. The higher weight classes are not deficient in heterozygotes in 10 mo old oysters, showing a positive value of $D$ and a negative value of $D$ in the smallest group of the cohort, while the opposite can be observed in 36 mo old oysters at 2 loci.

A positive and significant relation between standard dry weight and MLH was found for the 10 mo old juveniles of the cohort (Fig. 1a). After adjustment for the regressions of energy budget parameters on estimated somatic dry weight, there was a significant positive relationship between scope for growth and MLH among 10 mo old oysters (Table 4). Regressions of ingestion rate, absorption rate, net growth efficiency $\left(K_{2}\right)$ and total energy gains against MLH were each positive and significant (Table 4). Respiration rate (weight-specific metabolic costs) showed a negative and significant relationship with MLH, while excretion rate and total energy losses showed a negative trend to heterozygosity, but not significantly (Table 4) MLH explained $17.9 \%$ of the variation in weight-corrected metabolic energy gains and $8 \%$ of the variation in weight-specific metabolic costs (Table 4, Fig. 1).
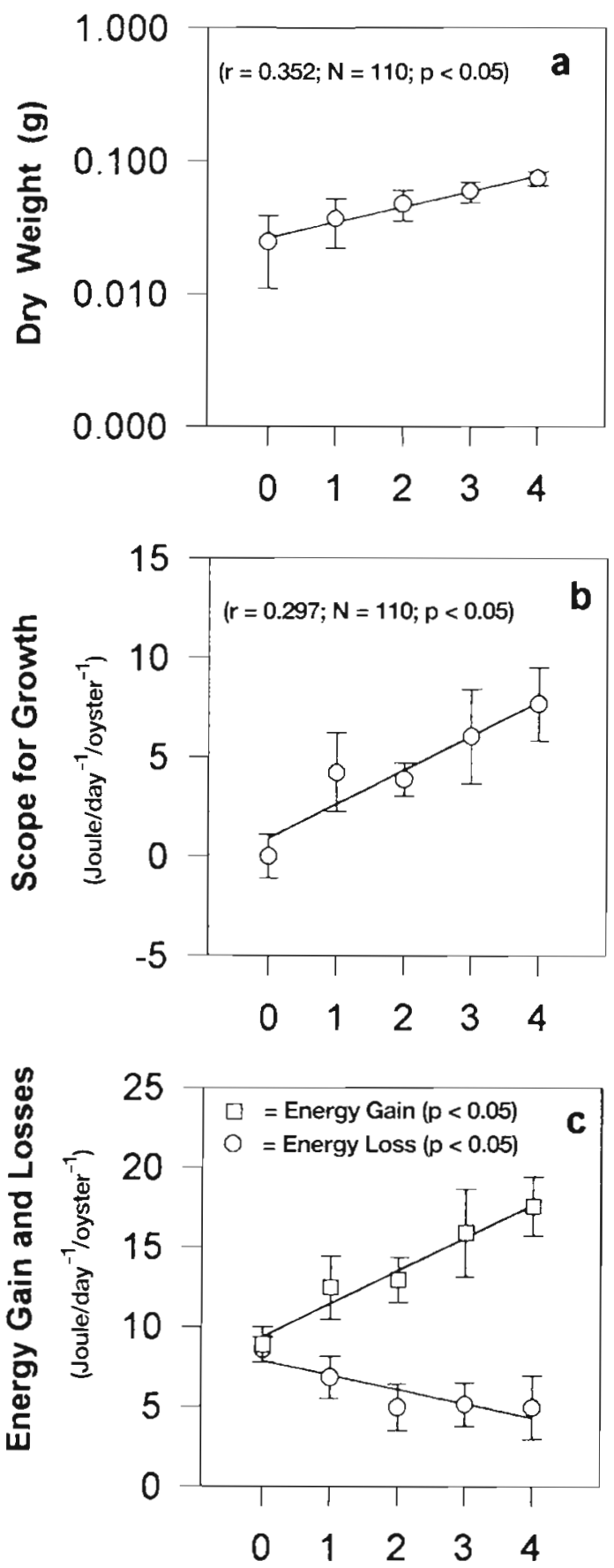

MEAN NUMBER HETEROZYGOUS LOCI/INDIVIDUAL

Fig. 1. Ostrea chilensis. Regressions of (a) dry weight, (b) scope for growth and (c) energy gain and losses on multiple-locus heterozygosity in 10 mo old oysters. Values are means \pm SE. See also Table 4

The regressions after adjustment of energy budget parameters on estimated somatic dry weight presented a significant negative relationship between scope for growth and MLH among 36 mo old oysters (Table 5). Regressions of ingestion rate, absorption rate, net 
Table 4. Ostrea chilensis. Analyses of weight-specific energy budget components on multiple-locus heterozygosity (MLH) in 10 mo old oysters. OM: organic matter; ns: not significant; $N=110_{i}{ }^{p} p<0.05$

\begin{tabular}{|c|c|c|c|}
\hline Parameter & Equation & $\mathrm{r}$ & $\mathrm{p}$ \\
\hline Filtration rate $\left(\mathrm{l} \mathrm{h}^{-1}\right.$ oyster $\left.{ }^{-1}\right)$ & $0.067-0.014(\mathrm{MLH})$ & 0.121 & ns \\
\hline Organic ingestion rate ( $\mathrm{mg} O \mathrm{OM} \mathrm{d}^{-1}$ oyster $\left.^{-1}\right)$ & $0.615+0.192(\mathrm{MLH})$ & 0.296 & $\cdot$ \\
\hline Absorption rate (mg OM d $\mathrm{d}^{-1}$ oyster $^{-1}$ ) & $0.712+0.144(\mathrm{ML} . H)$ & 0.282 & $\cdot$ \\
\hline Excretion rate (o $\mathrm{NH}_{4}-\mathrm{N} \mathrm{d}^{-1}$ oyster-1) & $36.876-0.521$ (MLH) & 0.073 & ns \\
\hline Respiration rate $\left(\mathrm{ml} \mathrm{O}_{2} \mathrm{~d}^{-1}\right.$ oyster $\left.^{-1}\right)$ & $0.456-0.085(\mathrm{MLH})$ & 0.391 & $\cdot$ \\
\hline Scope for growth ( $\mathrm{J}^{\mathrm{d}}{ }^{1}$ oyster $\left.^{-1}\right)$ & $2.748+0.842(\mathrm{MLH})$ & 0.297 & $\cdot$ \\
\hline Net growth efficiency $\left(K_{2}\right)$ & $0.211+0.162(\mathrm{MLH})$ & 0.469 & $\cdot$ \\
\hline Total energy gains $\left(\mathrm{J} \mathrm{d}^{-1}\right.$ oyster $\left.\mathrm{r}^{-1}\right)$ & $10.537+1.269(\mathrm{MLH})$ & 0.423 & $\cdot$ \\
\hline Total energy losses $\left(\mathrm{J} \mathrm{d}^{-1}\right.$ oyster $\left.{ }^{-1}\right)$ & $6.741-0.564(\mathrm{MLH})$ & 0.290 & ns \\
\hline
\end{tabular}

Table 5. Ostrea chilensis. Analyses of weight-specific energy budget components on multiple-locus heterozygosity (MLH) in 36 mo old oysters. OM: organic matter; ns: not significant; $N=142 ;{ }^{*} p<0.05 ; " ⿱ p p<0.01$

\begin{tabular}{|c|c|c|c|}
\hline Parameter & Equation & r & $\mathrm{p}$ \\
\hline Filtration rate $\left(1 \mathrm{~h}^{-1}\right.$ oyster $\left.{ }^{-1}\right)$ & $1.427-0.043(\mathrm{MLH})$ & 0.061 & ns \\
\hline Organic ingestion rate (mg OM d ${ }^{-1}$ oyster $^{-1}$ ) & $37.242-4.434(\mathrm{MLH})$ & 0.283 & $\cdot$ \\
\hline Absorption rate (mg OM d $\mathrm{d}^{-1}$ oyster $^{-1}$ ) & $32.365-4.261(\mathrm{MLH})$ & 0.254 & . \\
\hline Excretion rate $\left(\mathrm{g} \mathrm{NH}_{4}-\mathrm{N} \mathrm{d}^{-1}\right.$ oyster $\left.{ }^{-1}\right)$ & $232.798+13.512(\mathrm{MLH})$ & 0.116 & ns \\
\hline Respiration rate $\left(\mathrm{ml} \mathrm{O}_{2} \mathrm{~d}^{-1}\right.$ oyster $\left.{ }^{-1}\right)$ & $4.706+0.788(\mathrm{MLH})$ & 0.275 & $\cdot$ \\
\hline Scope for growth $\left(\mathrm{J} \mathrm{d}^{-1}\right.$ oyster $\left.{ }^{-1}\right)$ & $557.362-94.259(\mathrm{MLH})$ & 0.323 & $\cdot$ \\
\hline Net growth efficiency $\left(K_{2}\right)$ & $0.831-0.328(\mathrm{MLH})$ & 0.393 & $\because$ \\
\hline Total energy gains $\left(\mathrm{J} \mathrm{d}^{-1}\right.$ oyster $\left.{ }^{-1}\right)$ & $433.502-52.872(\mathrm{MLH})$ & 0.247 & $\cdot$ \\
\hline Total energy losses $\left(\mathrm{J} \mathrm{d}^{-1}\right.$ oyster $\left.^{-1}\right)$ & $111.634+11.641(\mathrm{MLH})$ & 0.223 & $\cdot$ \\
\hline
\end{tabular}

growth efficiency $\left(K_{2}\right)$ and total energy gains, against MLH were each negative and significant (Table 5). Respiration rate and total energy losses (weightspecific metabolic costs) each showed a positive and significant relationship with $M L H$, while excretion rate showed a negative trend to heterozygosity, but not significantly (Table 5). There was no relationship between standard dry weight and MLH. (Fig. 2a).

\section{DISCUSSION}

Deficiency of heterozygotes in marine bivalves is a well-known phenomenon. Laboratory studies (Mallet et al. 1985, Gaffney et al. 1990) and studies using wild populations (Gosling \& Wilkins 1985, Gosling \& McGrath 1990) in Mytilus edulis have found this deficiency. In oysters, several studies have reported this phenomenon (Singh \& Zouros 1978, Zouros et al. 1980 for Crassostrea virginica, Guiñez \& Gallegillos 1985 for Ostrea chilensis). The results in the present study, however, are not in accord with those reported by Singh (1982) where the average observed heterozygosity increased and average $D$ (over loci) decreased with increasing age in wild cohorts of $C$. virginica. In laboratory studies with mussels an overall deficiency of heterozygotes was found at the juvenile stage but not at the spat stage (Beaumont 1991), suggesting selection against heterozygotes as the most probable cause. Such selection would also explain the results found in the laboratory-produced cohort of $O$. chilensis in this study. Alvarez et al. (1989), working with $O$. edulis, report a strong negative correlation between heterozygosity and viability with a mean viability of heterozygote oysters for 1,2 and 3 loci of $0.51 \pm 0.12$, between 18 and 30 mo of age, a value that is close to the one found in the present study $(0.46 \pm 0.17)$.

A form of a balancing selection proposed by Singh (1982) could explain the increasing deficiency of heterozygotes with age, by genotype-dependent mortality after settlement. Ostrea chilensis broods its larvae within the mantle cavity until the eyed larvae stage, with a very short planktonic period that ranges between $5 \mathrm{~min}$ and $48 \mathrm{~h}$ (DiSalvo et al. 1983). The fast growing heterozygous spat will have higher food (phytoplankton) requirements after their settlement during the last week of December (summer), when the number of cells $\mathrm{l}^{-1}$ of natural phytoplankton shows a marked decrease in the Quempillén Estuary (Toro 1985, Senn 1993). These heterozygous individuals will then face starvation and mortality, producing the heterozygote deficiency in the later stages of the life cycle of the $O$. chilensis cohort (Toro \& Vergara 1995). Another alternative hypothesis to explain the increasing 

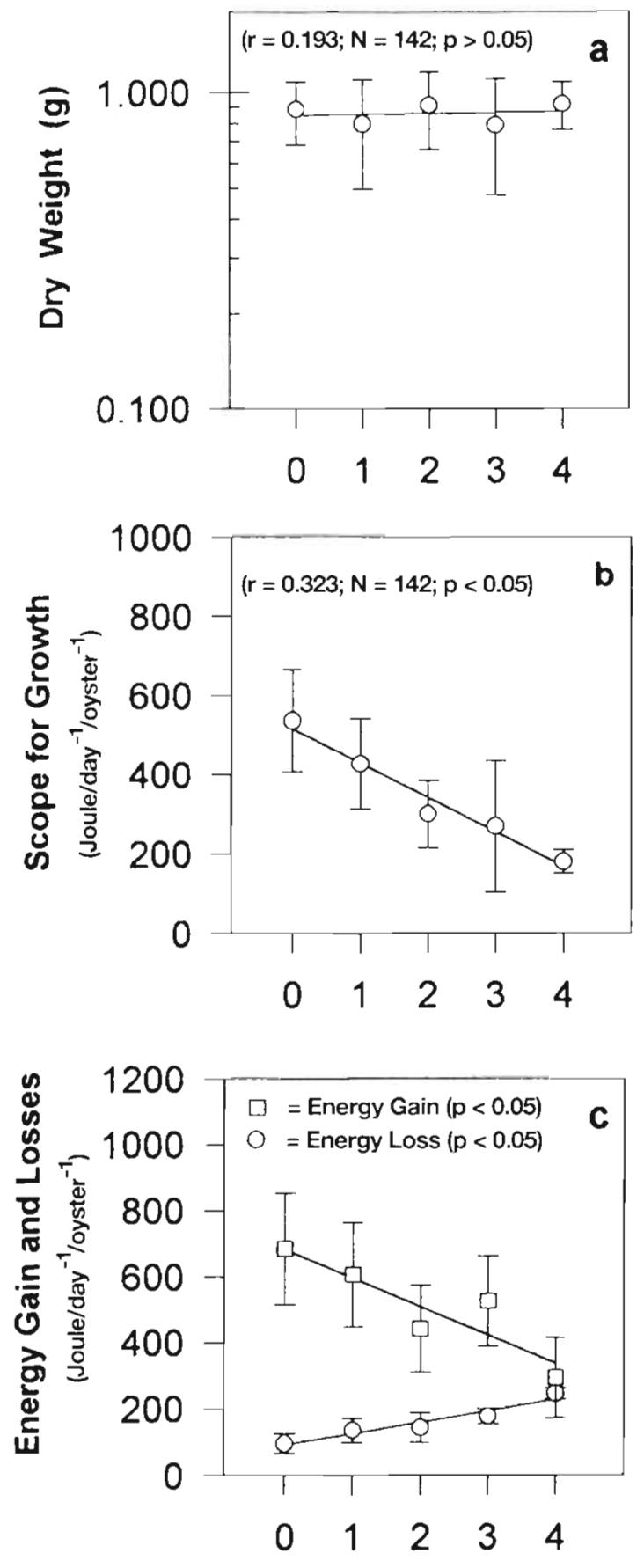

MEAN NUMBER HETEROZYGOUS LOCI/INDIVIDUAL

Fig. 2. Ostrea chilensis. Regressions of (a) dry weight, (b) scope for growth and (c) energy gain and losses on multiple-locus heterozygosity in 36 mo old oysters. Values are means $\pm \mathrm{SE}$. See also Table 5

deficiency of heterozygotes could be that multi-locus heterozygotes are victims of their own efficiencies at later stages of their life cycle. Reproduction is a very energy demanding process and many oysters succumb to disease and/or are metabolically spent after gameto- genesis (Chaparro 1995). It could be possible that these very efficient oysters overproduce gametes and then attempt to brood more offspring than they can care for and still remain healthy and/or continue growing.

The deficiency of heterozygotes was not evenly distributed among the weight classes within each cohort (Table 3), with negative values for $D$ in the smallest group and positive values of $D$ in the heaviest group for the 10 mo old cohort. The opposite was found in the 36 mo old cohort. This was reflected in the energy budget correlations, showing that the lower scope for growth was found within the more heterozygote deficient oysters (Figs. 1c \& 2c).

A lack of a strong single-locus effect between metabolic costs and heterozygosity does indicate that the influence of heterozygosity is additive across loci in the 10 mo old oysters, resulting in heterosis for genotypedependent growth rate (Fig. 3). This heterosis for growth rate has been observed in other mollusc species (Singh \& Zouros 1978, Garton et al. 1984, Koehn \& Gaffney 1.984).

These results for the 10 mo old oysters are in accordance with previous reports on the relationship between MLH and growth rate (Singh \& Zouros 1978, Zouros et al. 1980, Fujio 1982, Koehn \& Shumway 1982, Garton 1984, Garton et al. 1984, Koehn \& Gaffney 1984, Diehl et al. 1986, Rodhouse et al. 1986, Gentili \& Beaumont 1988, Koehn et al. 1988).

These results are in accordance with those carried out in older ( $>2$ yr) individuals by Foltz \& Zouros (1984) in Placopecten magellanicus and by Beaumont et al. (1985) in Pecten maximus. These authors failed to show a growth rate/heterozygosity correlation. The reason suggested by Rodhouse et al. (1986) is the increasing allocation of energy to gamete production in these older individuals. In bivalves the somatic growth exceeds gamete production in early life, reaches a peak in intermediate age individuals and then declines in later life, while gamete production is null or low in early stages of the life cycle, but increasing throughout the life of the bivalve (Thompson 1984). The relationship shown in Fig. 2a corresponds to standard somatic dry weight after spawning (during the brooding period), thus there were no gametes included in the weight. As stated before, Ostrea chilensis broods its larvae for a period of 5 to $8 \mathrm{wk}$, requiring higher energy costs during the brooding period that may contribute to weight loss (Chaparro et al. 1993). These higher energy costs can be reflected in the negative scope for growth shown in Fig. $2 \mathrm{~b}$ and also the higher oxygen consumption reflected in the total energy losses in Fig. 2c.

Although this cohort of oysters was produced in the laboratory using mass spawning, we calculated that at least 130 females had contributed larvae. Thus, this 
Fig. 3. Ostrea chilensis. Mean dry weight ( \pm standard error) of homozygous and heterozygous genotypes for each locus in 10 mo old oysters. (a) locus Lap; (b) locus Pgi; (c) locus $\mathrm{Pgm}$ and (d) locus $\mathrm{Ca}$
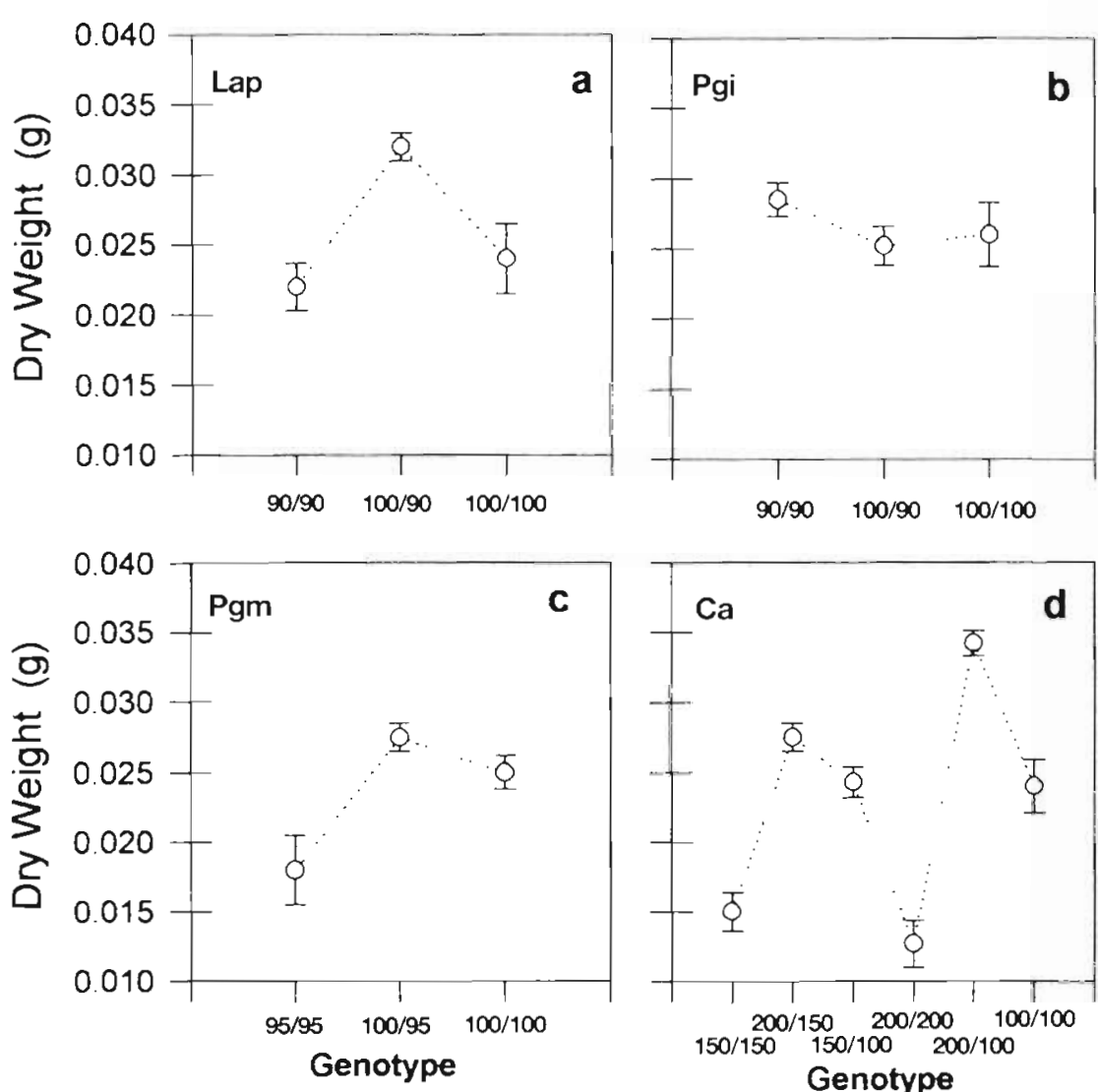

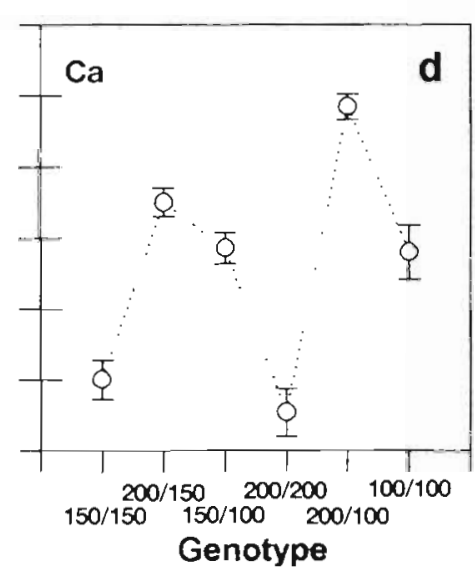

cohort cannot be treated as a product of restricted matings to explain the lack of a positive heterozygosity/ growth correlation in the presence of a significant deficiency of heterozygotes (Beaumont 1991)

Our findings are consistent with other reports that have demonstrated energetic advantages of more heterozygous individuals. In sexually immature juveniles of Ostrea chilensis produced by mass spawning in the laboratory, a positive correlation between growth rate and MLH can be found, while in adults the higher energy allocation for reproduction precludes the detection of this positive relationship with growth rate.

Acknowledgements. This paper is dedicated to the memory of our dear friend and colleague Dr Jürgen $\mathrm{E}$. Winter This work was supported by FONDECYT 91-0897, the Dirección de Investigación y Desarrollo UACH Grant S-94-18 and the International Foundation for Science IFS grant A/621

\section{LITERATURE CITED}

Ahmad M, Skibinsky DOF, Beardmore JA (1977) An estimate of the amount of genetic variation in the common mussel Mytilus edulis. Biochem Genet 15:833-846

Alvarez G, Zapata C, Amaro R, Guerra A (1989) Multilocus heterozygosity at protein loci and fitness in the European oyster, Ostrea edulis L. Heredity 63:359-372

Beaumont AR (1991) Genetic studies of laboratory reared mussels, Mytilus edulis: heterozygote deficiencies, het- erozygosity and growth. Biol J Linnean Soc 44:273-285

Beaumont AR, Gosling EM, Beveridge CM, Budd MD, Burnell GM (1985) Studies on heterozygosity and size in the scallop Pecten maximus (L.). In: Gibbs PE (ed) Proc 19th Eur Mar Biol Symp, Cambridge University Press, Cambridge, $\mathrm{p} 443-454$

Chaparro OR (1995) The brooding process in the Chilean oyster, Ostrea chilensis Philippi 1845. PhD thesis, Memorial University of Newfoundland, St. John's

Chaparro OR, Thompson RJ, Ward JE (1993) In vivo observations of larval brooding in the Chilean oyster, Ostrea chilensis Philipp1, 1845. Biol Bull 185:365-372

Connover RJ (1966). Assimilation of organic matter by zooplankton. Limnol Oceanogr 11:338-354

Diehl WJ, Gaffney PM, Koehn RK (1986) Physiological and genetic aspects of growth in the mussel Mytulus edulis. I. Oxygen consumption, growth, and weight loss. Physiol Zool 59:201-211

DiSalyo LH, Alarcon E, Martinez E (1983) Induced spat production from Ostrea chilensis Philippi 1845 in mid-winter Aquaculture 30:357-362

Elliot JM, Davison, W (1975) Energy equivalents of oxygen consumption in animal energetics. Oecologia 19:195-201

Foltz DW, Zouros E (1984) Enzyme heterozygosity in the scallop Placopecten magellanicus (Gmelin) in relation to age and size. Mar Biol Lett 5:255-263

Fujio Y (1982) A correlation of heterozygosity with growth rate in the Pacific oyster, Crassostrea gigas. Tohoku J Agric Res 33:66-75

Gaffney PM, Scott TM (1984) Genetic heterozygosity and production traits in natural and hatchery populations of bivalves. Aquaculture 42:289-302

Gaffney PM, Scott TM, Koehn RK, Diehl WJ (1990) Interrela- 
tionships of heterozygosity, growth rate and heterozygote deficiencies in the coot clam, Mulinia lateralis. Genetics $124: 687-699$

Garton DW (1984) Relationship between multiple locus heterozygosity and physiological energetics of growth in the estuarine gastropod Thais haemastoma. Physiol Zool 57: $530-543$

Garton DW, Koehn RK, Scott TM (1984) Multiple-locus heterozygosity and the physiological energetics of growth in the coot clam, Mulinia lateralis, from a natural population. Genetics 108:445-455

Gentili MR, Beaumont AR (1988) Environmental stress, heterozygosity, and growth rate in Mytilus edulis L. J Exp Mar Biol Ecol 120:145-153

Gosling EM, McGrath D (1990) Genetic variability in exposed-shored mussels, Mytilus spp. along an environmental gradient. Mar Biol 104:413-418

Gosling EM, Wilkins NP (1985) Genetics of settling cohorts of Mytilus edulis (L.): preliminary observations. Aquaculture $44: 115-123$

Guinez R, Gallegillos R (1985) Clinical variation in morphological distance between genotypes at the carbonic anhydrase locus in the Chilean oyster, Tiostrea chilensis (Philippi 1845) Chanley \& Dinamani, 1980. Braz J Genet 8:609-616

Hawkins AJS, Bayne BL, Day AJ (1986) Protein turnover, physiological energetics and heterozygosity in the blue mussel, Mytilus edulis: the basis of variable age-specific growth. Proc R Soc Lond (Ser B) 229:161-176

Koehn RK, Diehl WJ, Scott TM (1988) The differential contribution by individual enzymes of glycolysis and protein catabolism to the relationship between heterozygosity and growth rate in the coot clam, Mulinia lateralis. Genetics 118:121-130

Koehn RK, Gaffney PM (1984) Genetic heterozygosity and growth rate in Mytilus edulis. Mar Biol 82:1-7

Koehn RK, Shumway SE (1982) A genetic/physiological explanation for differential growth rate among individuals of the American oyster, Crassostrea virginica (Gmelin). Mar Biol Lett 3:35-42

Mallet AL, Zouros E, Gartner-Kepkay KE, Freeman KR, Dickie LM (1985) Larval viability and heterozygote deficiency in populations of marine bivalves: evidence from pair matings of mussels. Mar Biol 87:165-172

Mitton JB, Grant MC (1984) Associations among protein heterozygosity, growth rate and developmental homeostasis. A Rev Ecol Syst 15:479-499

Navarro JM, Winter JE (1982) Ingestion rate, assimılation efficiency and energy balance in Mytilus chilensis in relation to body size and different algal concentrations. Mar Biol 67:255-266

Packard GC, Boardman TJ (1988) The misuse of ratios, indices, and percentages in ecophysiological research. Physiol Zool 61:1-9

Rios CF (1979) Balance energético en poblaciones de Galaxias maculatus Jenyns (Salmoniformes: Galaxiidae). Medio Ambiente 4:24-39

Rodhouse PG, Gaffney PM (1984) Effect of heterozygosity on metabolism during starvation in the American oyster Crassostrea virginica. Mar Biol 80:179-187

Rodhouse PG, McDonald JH, Newell RIE, Koehn RK (1986) Gamete production somatic growth and multiple-locus enzyme heterozygosity in Mytilus edulis. Mar Biol 90:209-214

Selander RK, Smith MH, Yang SY, Johnson WE, Gentry JB (1971) Biochemical polymorphism and systematics in the genus Peromyscus. I. Vartation in the oldfield mouse (Peromyscus polionotus). University of Texas Publication No. 7103. Stud Genet 6:49-90
Senn CM (1993) Influencia del fitoplancton y de las variables ambientales asociadas sobre: la tasa de crecimiento de Ostrea chilensis (Philippi, 1845) en cinco localidades de la Isla de Chiloé, Chule. Thesis, Universidad Austral de Chile, Valetivia

Shaw ChR, Prasad R (1970) Starch electrophoresis of enzymes - a compilation of recipes. Bioch Genet 4:297-320

Singh SM (1982) Enzyme heterozygosity associated with growth at different developmental stages in oysters. Can J Genet Cytol 24:451-458

Singh SM, Zouros E (1978) Genetic variation associated with growth rate in the American oyster (Crassostrea virginuca). Evolution 32:342-353

Sokal RR, Rohlf FJ (1981) Biometry. WH Freeman, San FranCISCO

Solórzano L (1969) Determination of ammonia in natural waters by the phenol-hypochlonte method. Limnol Oceanogr 14:799-801

Thompson RJ (1984) Production, reproductive effort, reproductive value and reproductive cost in a population of the blue mussel Mytilus edulis from a subarctic environment. Mar Ecol Prog Ser 16:249-257

Thompson RJ, Bayne BL (1974) Some relationships between growth, metabolism and food in the mussel Mytilus edulis. Mar Biol 27:317-326

Toro JE (1985). Annual cycle and composition of the phytoplankton in the Quempillén River estuary, southern Chile. Estuar Coast Shelf Sci 21:461-469

Toro JE, Aguila PR (1995) Cruzamientos factoriales con cinco poblaciones de ostra chilena (Ostrea chilensis Philippi 1845 ) aisladas geograficamente. Arch Med Vet (Valdivia) $27: 69-80$

Toro JE, Chaparro OR (1990) Conocimiento biológico de Ostrea chilensis Philippi 1845: impacto y perspectivas de la ostricultura en Chile. In: Hernadez A (ed) Cultivo de moluscos en America Latina. CIID-Canada, Bogotá, p $231-264$

Toro JE, Newkirk GF (1991) Response to artificial selection and realized heritability estimate for shell height in the Chilean oyster Ostrea chilensis. Aquat Living Resour 4: $101-108$

Toro JE, Varela CS (1988) Growth and mortality of oysters, Ostrea chilensis Ph., grown on trays and on the conventional 'cultch' system in the Quempillén River estuary. Aquacult Fish Mgmt 19:101-104

Toro JE, Vergara AM (1995) Evidence for selection against heterozygotes: post-settlement excess of allozyme homozygosity in a cohort of the Chilean oyster, Ostrea chilensis Philippi, 1845. Biol Bull 188:117-119

Vergara AM, Toro JE, Paschke KA (1992). Relaciones entre variables fisiológicas, heterocigosidad y eficiencia de crecimiento en Tiostrea chilensis, (Philippi 1845). Rev Biol Mar Valparaíso 27:283-297

Warren CE, Davis GE (1967) Laboratory studies on the feeding bioenergetics and growth of fish. In: Gerking SD (ed) The brological basis of freshwater fish production. Blackwell Scientific, Oxford. p 175-214

Whyte JNC (1987) Biochemical composition and energy content of six species of phytoplankton used in mariculture of bivalves. Aquaculture 60:231-241

Winter JE, Acevedo MA, Navarro JM (1984) Quempillén estuary, an experimental oyster cultivation station in southern Chile. Energy balance in Ostrea chilensis. Mar Ecol Prog Ser 20:151-164

Zouros E, Singh SM, Miles HE (1980) Growth rate in oysters: an overdominant phenotype and its possible explanations. Evolution 34:856-867 